\title{
The Effect of Initial pH and Retention Time on Boron Removal by Continuous Electrocoagulation Process
}

\author{
A.E. Yilmaz ${ }^{1}$, I. Cengiz ${ }^{1}$, T.M. Massara ${ }^{2,3}$, T.M..Yilmaz ${ }^{1}$, O.T. Komesli ${ }^{1}$, P. Stanchev ${ }^{3}$, E. Katsou ${ }^{2,3}$ \\ ${ }^{1}$ Department of Environmental Engineering, Faculty of Engineering, Ataturk University, 25240, Erzurum, \\ Turkey. \\ ${ }^{2}$ Institute of Environment, Health and Societies, Brunel University London, Uxbridge Campus, Middlesex, \\ UB8 3PH, Uxbridge, UK. \\ ${ }^{3}$ Department of Mechanical, Aerospace and Civil Engineering, Brunel University London, Uxbridge \\ Campus, Middlesex, UB8 3PH, Uxbridge, UK.
}

Corresponding Author: Evina Katsou (Evina.Katsou@brunel.ac.uk; Tel.: +44 (0)1895 265721) 


\begin{abstract}
In this study, factors influencing boron removal via the continuous electrocoagulation process were investigated at lab-scale. Different influent $\mathrm{pH}$ values $(4,5,6,7.45$ and 9) and contact times $(10,25,50$ and $100 \mathrm{~min}$ ) were examined as variable parameters. Plate-type aluminium electrodes with $5 \mathrm{~mm}$ distance between them were used. All the experiments were conducted in continuous mode and the current density was kept constant at $5 \mathrm{~A}$ throughout the whole experimental period. The initial boron concentration was selected to be $1000 \mathrm{mg} \mathrm{L}^{-1}$. The first set of experiments concerning the influence of the influent $\mathrm{pH}$ showed that the highest boron removal $(67 \%)$ was obtained at $\mathrm{pH}=6$ since it was the optimal $\mathrm{pH}$ for boron precipitation through aluminium borate formation. Under the constant current density of the study and with the initial $\mathrm{pH}$ adjusted to 6 , increasing the duration of the electrocoagulation process from 10 to $100 \mathrm{~min}$ resulted in raising the boron removal from 45 to $79 \%$ during the second set of experiments. The greater duration of the electrocagulation process enabled higher aluminium dissolution, thus allowing the existence of a higher number of coagulants within the reactor. Moreover, it enhanced boron precipitation because of the longer contact time between the boron ions and the coagulants. After optimizing significant parameters such as the influent $\mathrm{pH}$ and the electrocagulation duration, the continuous electrocoagulation process was found to constitute an effective alternative for boron removal.
\end{abstract}

Keywords Boron, continuous electrocoagulation process, influent $\mathrm{pH}$, electrocoagulation duration, contact time

\title{
1. Introduction
}

Boron (B) is a trace element widely distributed in the earth's hydrosphere and lithosphere. In the lithosphere, boron can be found in soil or rocks with its average concentration being $10 \mathrm{mg} \mathrm{kg}^{-1}$ in the earth's crust, thus taking up only $0.001 \%$ of the earth's elemental composition [1-2]. In the hydrosphere, its average concentration is about $4.5 \mathrm{mg} \mathrm{L}^{-1}$ in seawater, whereas its concentration varies from 0.3 to $100 \mathrm{mg} \mathrm{L}^{-1}$ in groundwater [1-3]. In nature, elemental boron hasn't been found yet; it is traced in compounds together with other elements.

In the recent years, a significant increase in the boron concentration in surface water has been observed. The concentration increases/fluctuations among different areas are related to both natural and anthropogenic 
factors. Weathering of rocks and leaching of salt deposits can be counted as natural causes. Then, boron deposits appear on the shoreline. Due to its high volatility, boron can be found in the rainfall at coastal areas. Industrial activities can additionally trigger an increase of the boron amount in surface waters. Boric acid $\left(\mathrm{BH}_{3} \mathrm{O}_{3}\right)$ and boron salts are widely used as a preservative in many industrial sectors. Boron is also detected in the "acid rain" [4-6]. Recently, boron compounds have been utilized in the production of high-energy fuels, coolants and catalysts [7]. Hence, the boron concentration in surface water at industrial and urban areas is constantly increasing. Therefore, boron removal from water is particularly significant not only for countries with natural deposits but also for those with high industrial activity.

Electrocoagulation consists of an in-situ generation of coagulants by an electrical dissolution of iron or aluminium electrodes. The metal ions generation takes place at the anode; hydrogen gas is released from the cathode. The hydrogen gas would also help the flocculated particles to float out of the water, and therefore, the process is often called electroflocculation [8]. Typically, aluminium, iron, carbon, mild steel, graphite and titanium plates are used as electrodes in the electrocoagulation process. Iron and aluminium in specific have been reported to be very effective in pollutant removal [13-14].

In this work, a lab-scale reactor was implemented to investigate the effectiveness of the continuous electrocoagulation process for boron removal from a high-concentration boron solution prepared synthetically. To this end, process optimization was attempted through testing the effect of different influent $\mathrm{pH}$ values and contact times.

\section{Materials and Methods}

In this study, maintaining high boron concentration was decided to mimic boron industry wastewater. Synthetic wastewater samples were prepared for the experiments using borax (sodium tetraborate decahydrate: $\mathrm{Na}_{2} \mathrm{~B}_{4} \mathrm{O}_{7}$ ) from Merck with $99.99 \%$ purity. The boron solution of $1000 \mathrm{mg} \mathrm{L}^{-1}$ was prepared by dissolving $4647.28 \mathrm{mg}$ of borax dried at $105^{\circ} \mathrm{C}$ in $1 \mathrm{~L}$ of distilled water.

A lab-scale plexiglass reactor $(16 \mathrm{~cm} \times 8 \mathrm{~cm} \times 8 \mathrm{~cm})$ was used for the experiments (Fig. 1). Two groups of aluminium electrodes, alternating between anodes and cathodes by eight plates of each type, were arranged vertically. The net spacing between the aluminium electrodes was $5 \mathrm{~mm}$. They were connected to the terminals of a direct current (DC) power supply characterized by 0-10 A range for current and 0-30 V range 
for voltage. At the beginning of each run, the prepared boron solution (i.e. $1000 \mathrm{mg} \mathrm{L}^{-1}$ ) was fed into the reactor. The moment the DC power supply was switched on was considered as starting time for each run.

The analytical determination of boron in the samples was conducted potentiometrically by using mannitol $\left(\mathrm{C}_{6} \mathrm{H}_{14} \mathrm{O}_{6}\right)$, which forms a complex compound with $\mathrm{BH}_{3} \mathrm{O}_{3}$. For this purpose, boron analyses were carried out as follows: after filtering the samples, $5 \mathrm{~g} \mathrm{C}_{6} \mathrm{H}_{14} \mathrm{O}_{6}$ were added. The solution was then titrated with $0.5 \mathrm{~N}$ of potassium hydroxide $(\mathrm{KOH})$ until the $\mathrm{pH}$ was adjusted to 7.6. The boron amount was calculated via the $\mathrm{KOH}$ consumption [9]. This method was selected to eliminate any potential aluminium interference in the boron detection that is likely in the case of spectrophotometric methods such as the Carmin, Azomethine-H and Curcumin methods [10].

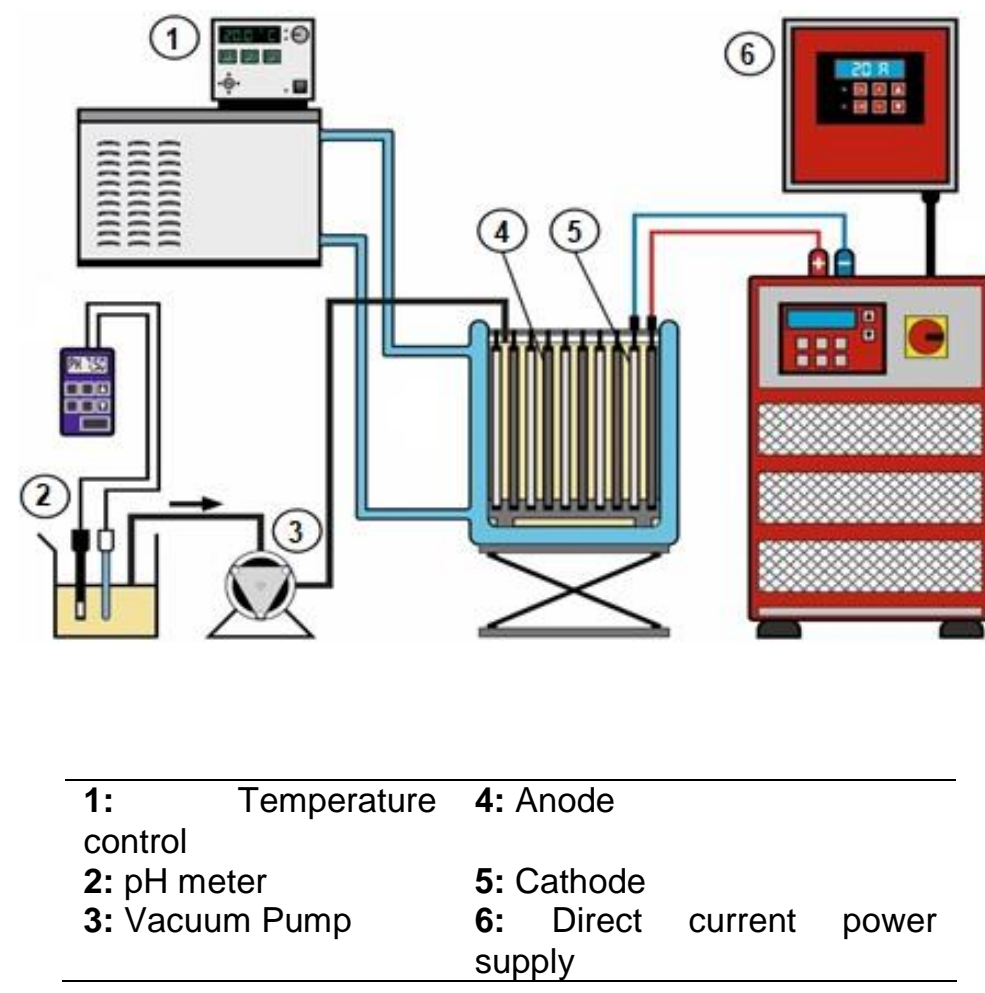

Figure 1. Process diagram of the experimental system applied in this study for boron removal under different influent $\mathrm{pH}$ values and retention times.

\section{Results}

During the runs, the effect of parameters such as the influent $\mathrm{pH}$ as well as different electrocoagulation durations on boron removal were investigated after ensuring that current density and initial boron concentration were kept unchanged during all sets of experiments. Supporting electrolyte can be used in 
similar experiments. Its conductivity impacts on the cell resistance. In addition, the electrolyte solution properties influence the interaction with the electroactive species, thus affecting the electrode reactions [1516]. However, the investigation of the effect of this parameter was out of the scope of this work and, therefore, supporting electrolyte was not used in the current study.

\subsection{Initial pH}

The initial $\mathrm{pH}$ is amongst the most important factors affecting the performance of the electrocoagulation processes [16-17]. The aluminium hydroxide $\left(\mathrm{Al}(\mathrm{OH})_{3}\right)$ is amphoteric. Hence, the formation of the $\mathrm{Al}(\mathrm{OH})_{3}$ flocs is significantly affected by the $\mathrm{pH}$. Within a $\mathrm{pH}$ range of 4-9, aluminium hydroxides with positive charge (e.g. $\left.\mathrm{Al}(\mathrm{OH})^{2+}, \mathrm{Al}(\mathrm{OH})_{2}{ }^{+}, \mathrm{Al}_{2}(\mathrm{OH})_{2}{ }^{4+}, \mathrm{Al}(\mathrm{OH})_{3}, \mathrm{Al}_{13}(\mathrm{OH})_{32}{ }^{7+}\right)$ and high adsorption capacity are formed. As soon as the $\mathrm{pH}$ exceeds the value of 9 , the dominant aluminium form is tetrahydroxyaluminate ion $\left(\mathrm{Al}(\mathrm{OH})_{4}{ }^{-}\right)$which, however, dissolves and does not form flocs $[11,16,18]$.

In this study, the $\mathrm{pH}$ effect on boron removal through electrocoagulation was examined by conducting experiments at different influent $\mathrm{pH}$ values (i.e. 4, 5, 6, 7.45 and 9); current density was kept constant at $5 \mathrm{~A}$ and the electrocoagulation duration was $50 \mathrm{~min}$. The results showed that boron removal increased from 57 to $67 \%$ with the $\mathrm{pH}$ increase from 4 to 6 . On the contrary, further $\mathrm{pH}$ increase to 9 resulted in decreasing the boron removal 52\% (Fig. 2). According to the obtained experimental results, optimum boron removal was achieved at $\mathrm{pH}=6$. Solid $\mathrm{Al}(\mathrm{OH})_{3}$ is the dominant form especially when the $\mathrm{pH}$ is between 6 and 7 [18-19]. It is likely that an initial $\mathrm{pH}$ equal to 6 provided the optimal conditions for boron precipitation through the formation of aluminium borate $\left(\mathrm{AlBO}_{3}\right)$.

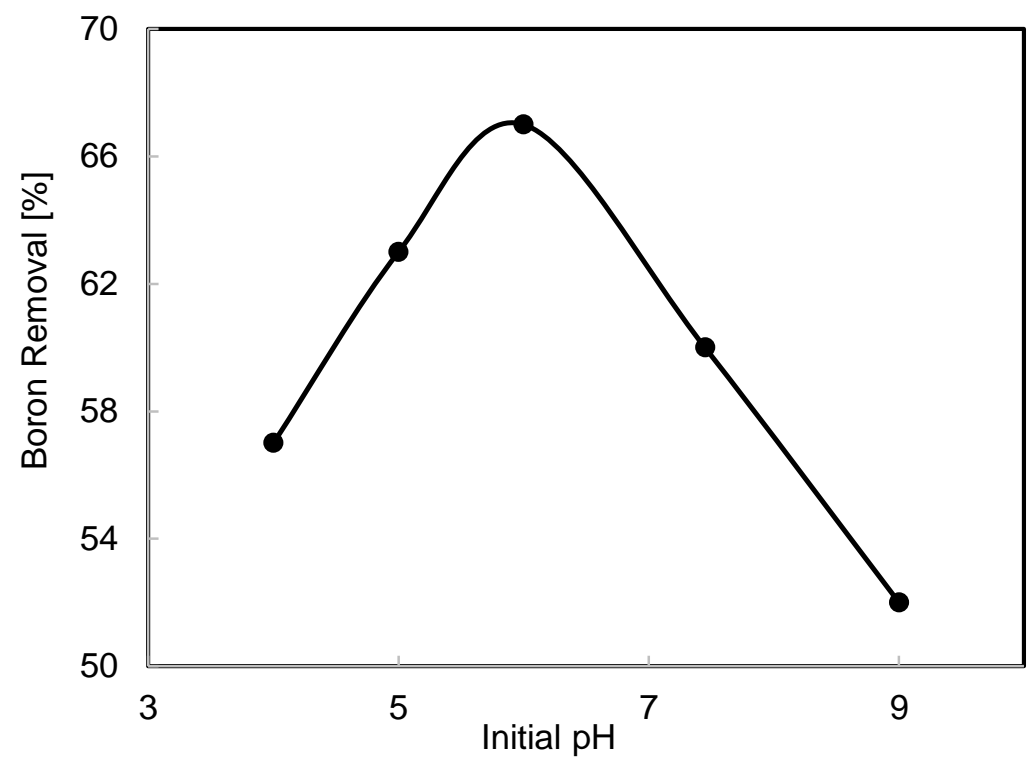


Figure 2. Effect of different influent $\mathrm{pH}$ values on boron removal. The current intensity was kept constant at $5 \mathrm{~A}$ and the electrocoagulation duration was $50 \mathrm{~min}$.

In addition, the effect of different influent $\mathrm{pH}$ values on the effluent $\mathrm{pH}$ measured at the end of the reaction time (i.e. $50 \mathrm{~min}$ ) is shown in Fig. 3. The $\mathrm{pH}$ increases whilst the electrocoagulation proceeds because of the hydrogen evolution at the cathode $[16,19]$. The highest the influent $\mathrm{pH}$, the highest the measured $\mathrm{pH}$ at the end of the electrocoagulation process.

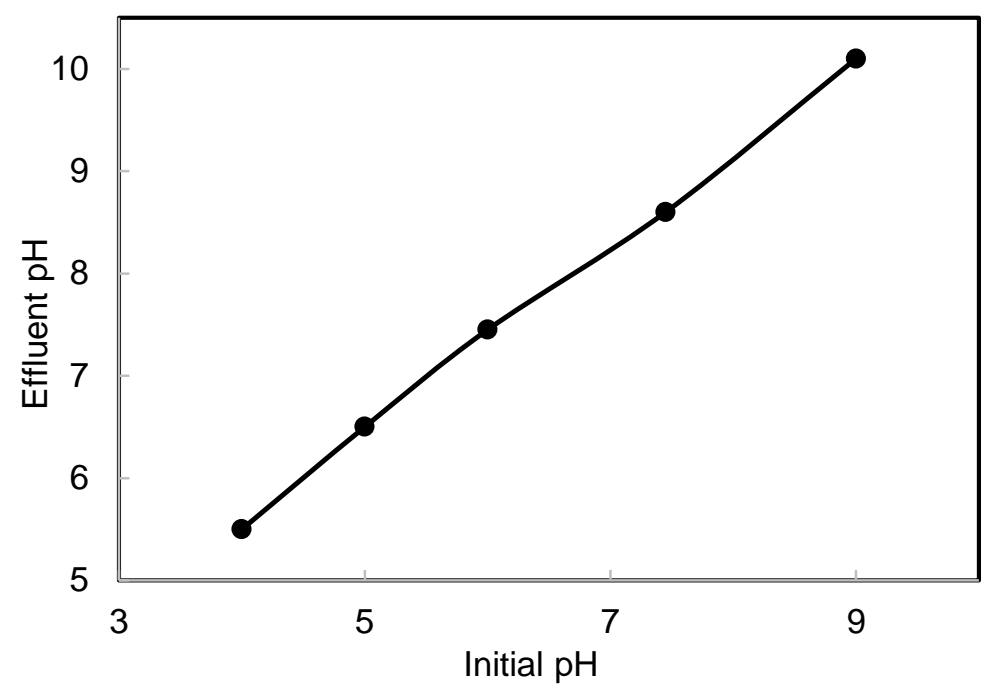

Figure 3. The change in the $\mathrm{pH}$ at the end of the electrocoagulation process for each of the different tested influent $\mathrm{pH}$ values. The current intensity was kept constant at $5 \mathrm{~A}$ and the electrocoagulation duration was 50 $\min$.

\subsection{Duration of electrocoagulation process}

The decision upon the duration of the electrolysis is another important factor that determines the pollutants removal $[12,16]$. While exploring the electrocagulation duration effect, the current density was kept constant at $5 \mathrm{~A}$. The influent $\mathrm{pH}$ was adjusted to 6 according to the results of the previous section. As shown in Fig. 4 , comparable changes in the boron removal were observed as the electrolysis time increased. Boron removal equal to 45, 53, 65 and 79\% was measured for durations equal to 10, 25, 50 and 100 min, respectively. After 10 min of electrolysis, the removal efficiency was quite low (45\%). Thus, an operation time of 10 min was found insufficient to achieve satisfying boron removal. Increasing the duration of the electrocoagulation process caused a considerable rise in the removal rates with the highest one (79\%) occurring at the highest tested operation length (100 $\mathrm{min})$. 


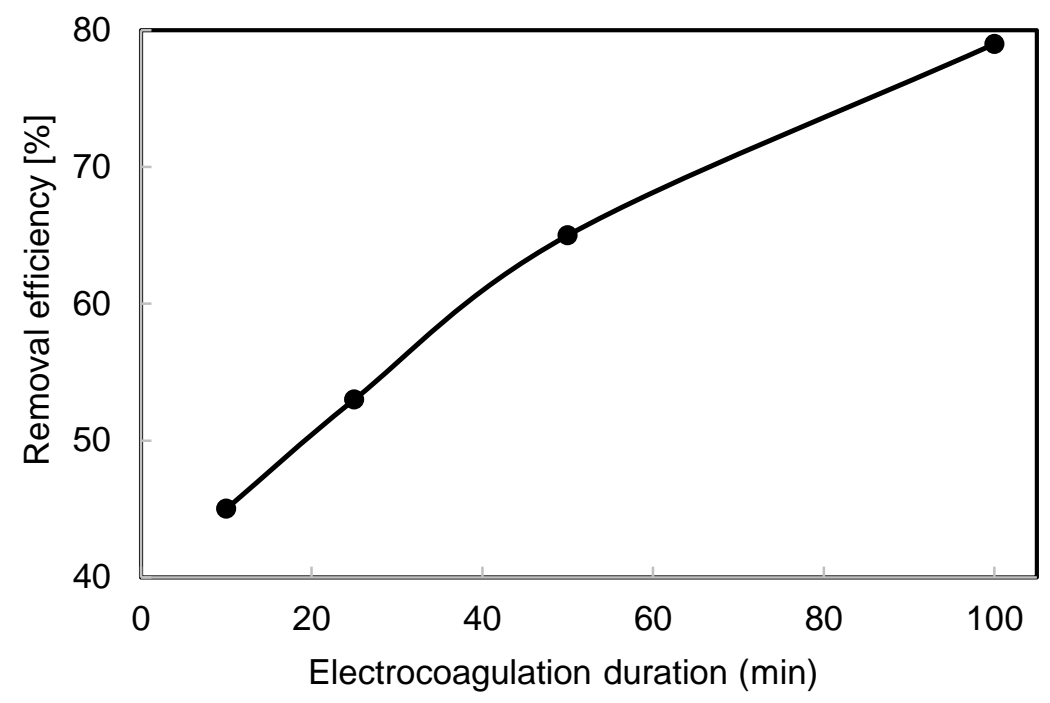

Figure 4. The effect of the duration of the electrocagulation process on boron removal. The current intensity was kept constant at $5 \mathrm{~A}$ and the influent $\mathrm{pH}$ was 6.

Providing more time for the electrocagulation process results in increasing the amount of the electrogenerated $\mathrm{Al}^{3+}$, thus leading to the production of a higher number of flocs comprised of insoluble monomeric and polymeric aluminium hydroxides. Moreover, it is translated into a longer contact time between the heavy metal ions and the flocs. Therefore, more heavy metal ions are removed through adsorption and coprecipitation with the flocs $[12,16]$.

\section{Discussion}

In the current study, boron removal from a boron-containing solution prepared synthetically was explored by employing the continuous electrocoagulation process with plate-type aluminium electrodes. The effect of changing operational variables (i.e. influent $\mathrm{pH}$ and retention time) on the process performance was examined. The current intensity was kept constant at $5 \mathrm{~A}$ throughout the study. With respect to the initial $\mathrm{pH}$ effect, various influent $\mathrm{pH}$ values were tested (4, 5, 6, 7.45 and 9) with the optimal boron removal (67\%) occurring at $\mathrm{pH}=6$. This result was supported by $\mathrm{pH}$-related activity for aluminium hydroxides. At $\mathrm{pH}=6$, $\mathrm{Al}(\mathrm{OH})_{3}$ is the dominant aluminium hydroxide form, thus enhancing boron precipitation via $\mathrm{AlBO}_{3}$ formation.

Moreover, increasing the electrocoagulation duration from 10 to 100 min was observed to increase boron removal from $45 \%$ to $79 \%$. Under constant current density $(5 \mathrm{~A})$ and with the initial $\mathrm{pH}$ adjusted to 6 , 
extending the electrocoagulation process enabled higher anodic dissolution and, thus, higher coagulants release. The existence of more coagulants per unit of pollutants within the reactor led to increased boron removal.

This study showed that the continuous electrocoagulation process can constitute an appropriate treatment for boron removal after optimizing important operational parameters such as the initial $\mathrm{pH}$ and the process duration. Future work can focus on the optimization of other parameters such as current density and influent flow rate.

\section{Acknowledgements}

T.M. Massara is grateful to the Natural Environment Research Council (NERC) of the UK for the 4-year full PhD studentship.

\section{References}

[1] Hilal, N., Kim, G.J., Somerfield, C.: Boron removal from saline water: a comprehensive review. Desalination 273, 23-35 (2011)

[2] Bodzek, M.: The removal of boron from the aquatic environment-state of the art. Desalin. Water Treat. $57,1107-1131(2016)$

[3] Wang, B., Guo, X., Bai, P.: Removal technology of boron dissolved in aqueous solutions -a review. Colloids Surf. A Physicochem. Eng. Asp. 444, 338-344 (2014)

[4] Wyness, A.J., Parkaman, R.H., Neal, C.: A summary of boron surface water quality data throughout the European Union. Sci. Total Environ. 314-316, 255-269 (2003)

[5] Badruk, M., Kabay, N., Demircioglu, M., Mordogan, H., Ipekoglu, U.: Removal of boron from wastewater of geothermal power plant by selective ion-exchange resins. I. Batch sorption-elution studies. Sep. Sci. Technol. 34 (13), 2553-2569 (1999)

[6] Melnyk, L., Goncharuk, V., Butnyk, I., Tsapiuk, E.: Boron removal from natural and wastewaters using combined sorption membrane process. Desalination 185, 147-157 (2005)

[7] Sahin, S.: A mathematical relationship for the explanation of ion exchange for boron removal. Desalination 143, 35-43 (2002) 
[8] Can, B.Z., Boncukcuoglu, R., Yılmaz, A.E., Fil, B.A.: Arsenic and Boron Removal by Electrocoagulation with Aluminum Electrodes. Arab. J. Sci. Eng. 41 (6), 2229-2237 (2016)

[9] Yılmaz, A.E., Boncukcuoğlu, R., Kocakerim, M.M., Kocadağıstan, E.: An empirical model for kinetics of boron removal from boron containing wastewaters by the electrocoagulation method in a batch reactor. Desalination 230, 288-297 (2008)

[10] Sah, R.N., Brown, P.H.: Boron determination-A review of analytical methods. Microchem. J. 56, 285304 (1997)

[11] Bard, A.J., Parsons, R., Jordan, J.: Standard Potentials in Aqueous Solution. Marker Dekker, New York (1985)

[12] Lu, J., Li, Y., Yin, M., Ma, X., Lin, S.: Removing heavy metal ions with continuous aluminum electrocoagulation: A study on back mixing and utilization rate of electro-generated Al ions. Chem. Eng. J. 267, 86-92 (2015)

[13] Cañizares, P., Jiménez, C., Martínez, F., Sáez, C., Rodrigo, M.A.: Study of the Electrocoagulation Process Using Aluminum and Iron Electrodes. Ind. Eng. Chem. Res. 46 (19), 6189-6195 (2007)

[14] Mahmoud, M.S., Farah, J.Y., Farrag, T.E.: Enhanced removal of Methylene Blue by Electrocoagulation using Iron Electrodes. Egypt. J. Pet. 22 (1), 211-216 (2013)

[15] Huang, C.H., Chen, L., Yang, C.L.: Effect of anions on electrochemical coagulation for cadmium removal. Sep. Purif. Technol. 65, 137-146 (2009)

[16] Tezcan Un, U., Koparal, A.S., Bakir Ogutveren, U.: Fluoride removal from water and wastewater with a bach cylindrical electrode using electrocoagulation. Chem. Eng. J. 223, 110-115 (2013)

[17] Daneshvar, N., Ashassi-Sorkhabi, H., Tizpar, A.: Decolorization of orange II by electrocoagulation method. Sep. Purif. Technol. 31(2), 153-162 (2003)

[18] Gupta, V.K., Ali, I.: Chapter 6 - water treatment by electrical technologies, environmental water: advances in treatment. Rem. Recycl. 155-178 (2013)

[19] Tezcan Un, U., Koparal, A.S., Bakir Ogutveren, U.: Electrocoagulation of vegetable oil refinery wastewater using aluminum electrodes. J. Environ. Manage. 90 (1), 428-433 (2009) 